UDC 615.254.1:547.757

DOI: $10.15587 / 2519-4852.2017 .113361$

\title{
THE IMPACT OF INDOLINOREN ON HISTROTRUCTURE OF KIDNEY ON THE GLIXERROID ACUTE RENAL FAILURE MODEL
}

\author{
(c) A. Markina, O. Mishchenko, Yu. Laryanovska
}

Гостра ниркова недостатність є одним з найтяжчих станів ураження нирок. Даний синдром характеризується різким зниженням видільної функиї нирок з азотемією та значними порушеннями водносольового гомеостазу, щио зумовлює застосування діуретиків.

Метою дослідження було вивчення впливу нового похідного 2-оксоіндоліну під умовною назвою “Індолінорен” на гістоструктуру нирок щурів із експериментальною глічероловою гострою нирковою недостатністю.

Матеріали та методи. Гостру ниркову недостатність в експерименті відтворювали внутрішньом'язовим уведенням шурам 50 \% розчину глічеролу у дозі 10 мл/кг. Виконані дослідження не суперечать загальноприйнятим біоетичним нормам, проведені з дотриманням відповідних міжнародних положень щзодо проведення експериментальних досліджень. Досліджувану сполуку “Індолінорен” уводили внутрішньо илунково в умовно терапевтичній дозі 29,5 мг/кг за діуретичною активністю. Препаратом порівняння був петльовий діуретик - фуросемід (5 мг/кг).

Результати та обговорення. Отримані дані в результаті дослідження гістроструктури нирок свідчать про потужну нефропротекторну дію сполуки “Індолінорен”.

Встановлено, щчо досліджувана сполука “Індолінорен” зменшує некроз нефрочитів канальців головних відділів нефронів та зменшує обструкцію просвіту канальців гомогенними циліндрами в 1,7 разу відносно групи контрольної патології. На фоні введення “Індолінорену” відмічено відсутність дезорганізації та дистрофії нефроччитів дистальних та проксимальних частин канальців нефронів, виразно зменшена кількість канальців у кортико-медулярній зоні та мозковому шарі, тобто прояви гострого ураження переважно залишаються на рівні кори нирки. Встановлено, щзо за вираженістю нефропротекторного впливу на гістоструктуру нирок щурів з гострою нирковою недостатністю нова досліджувана сполука з умовною назвою "Індолінорен” не поступається петльовому діуретичному засобу фуросеміду.

Висновки. На моделі глічеролової гострої ниркової недостатності сполука “Індолінорен” виявляє потужну нефропротекторну дію, суттєво знижуючи патологічні прояви у системі канальців нефронів. Сполука “Індолінорен” сприяє зменшенню некрозу нефронів, вакуольної дистрофії нефротелію та обструкиї просвіту канальців гомогенними ичиліндрами.Прояви гострого ураження переважно залишаються на рівні кори нирки

Ключові слова: індолінорен, похідні 2-оксоіндоліну, гостра ниркова недостатність, діуретичні засоби, фуросемід, гліиерол

\section{Introduction}

According to statistics, the frequency of acute renal failure syndrome (ARF) is 30-50 cases per 1 million population per year, and in one of them it is necessary to use hemodialysis for treatment [1]. In the structure of nephrological diseases, ARF takes $10 \%$ of cases. The ARF may be accompanied by various complications, sometimes causing death, but it is one of the few syndromes in which complete recovery of the organ function can be achieved [2,3]. Mortality of patients with ARF ranges from 0.2 to $2 \%[4,5]$.

2. The urgency of the topic and its relevance to important practical issues

The urgency of the problem of ARF caused, firstly, by the widespread causes of its occurrence and severe complications, and secondly, the lack of noticeable progress in the treatment and prevention of this syndrome in recent years. In developed countries, the number of cases of ARF associated with polypharmacy and sensitization to drugs has increased by 6-8 times over the past 10 years. The frequency of post operative acute renal and multiple organ failure, which is associated with an increase in the complexity of surgical interventions, has also grown [3]. An increase in the number of cases of transient neuralgia in the terminal stage of chronic renal failure has been noticed too.

3. An analysis of recent researches and publications on the solution of this problem

Diuretics are widely used in the treatment of ARF, in particular to exclude the oliguria, but may provide a number of side effects [4]. Therefore, the search for new safe medicines that can positively affect on the course of $\mathrm{ARF}$ is one of the important tasks of experimental pharmacology.

The analysis of literary sources has shown that derivatives of 2-oxoindoline show diverse pharmacological activity, in particular diuretic, and therefore they are perspective for the search and creation on their basis highly effective and low-toxic preparations with diuretic action [6].

\section{Formulating of the task}

The purpose of this work was to study the effects of the new derivative 2-oxoindoline with the conditional name "Indolinoren", for which diuretic activity was established [6] and the ability to improve the renal excreto- 
ry function under the conditions of the ARF [7] on histostructure of kidney of rats under the conditions of this pathology.

\section{Presentation of the main research material} (methods and objects) with the justification of the results

Materials and methods of research. The subject of the pharmacological study is the compound (the conditional name "Indolinoren"), which is the propyl ester $\mathrm{N}$-[(2-oxoindolinylidene-3)-2-oxacetyl] valine (Fig. 1) synthesized at the department of analytical chemistry of NPhU under the guidance of prof. Kolisnyk S.V.<smiles>CCOC(=O)C(NC(=O)/C(O)=C1\C(=O)Nc2ccccc21)C(C)C</smiles>

Fig.1. Chemical structure of propyl ester $\mathrm{N}$-[(2-oxoindolinylidene-3)-2-oxacetyl] valine compound "Indolinoren"

For the study, was used the compound in the conditionally therapeutic dose of $29.5 \mathrm{mg} / \mathrm{kg}$ for diuretic activity, which was established during the previous studies.

In the experiment was used the glycerol model of ARF, which is reproduced by intramuscular administration to the test animals of $50 \%$ solution of glycerol in a dose of $10 \mathrm{ml} / \mathrm{kg}$ once [8]. Experiments were performed on 32 white non-linear rats weighing $180-220 \mathrm{~g}$. The performed researches do not contradict generally accepted bioethical norms, carried out in compliance with the relevant international regulations on conducting experimental research [9]. Experimental animals were divided into 4 groups (8 animals per group): group I - intact control; group II - rats with ARF without treatment (control group); III - rats with ARF, which received "Indolinoren" in the conditional dose of $29.5 \mathrm{mg} / \mathrm{kg}$, in the form of a fine-dispersed aqueous suspension stabilized by a tween-80; IV - rats with ARF, which was administered with the comparator - furosemide (produced by the PJSC SIC "Borshchahivskiy CPP", Ukraine) at a dose of $5 \mathrm{mg} / \mathrm{kg}$ as an aqueous solution, which is included in the treatment protocols of the ARF in the clinics [10].

The test compound and furosemide were injected intragastrically in the therapeutic prophylactic mode for 3 days before the ARF simulation and within 2 days in the background of ARF. Sacrifice of animals of all groups was carried out 72 hours after the injection of glycerol. Samples of the kidneys were fixed in $10 \%$ of formalin solution, dehydrated in spirits of increasing strength, poured into celoidin-paraffin. The tissue sections were stained with hematoxylin and eosin [11]. Sacrifice was performed by overdose of ethereal anesthesia. On the sections, was performed a semi-quantitative assessment (in points) of the state of the tubular apparatus of the nephrons (the most vulnerable in this pathology) on the following morphological parameters: the severity of necrosis, vacuolar dystrophy of the nephrotelium, the presence of cylinders in the lumen of the tubules [11]. The evaluation results were presented in points: 0 points - no changes; 1 point - weak changes (affecting 10-15\% of tubules); 2 points - moderate changes (affect up to $25 \%$ of tubules); 3 points - expressive changes (affect up to $50 \%$ of tubules); 4 points - very distinct changes (affect up to $90 \%$ of tubules).

All received digital material was statistically processed using a nonparametric analogue of one factor analysis - the Kruskal-Wallis criterion, and then the Man-Whitney's criterion with Bonferoni's correction (the standard statistical software package "Statistika" 5.0, 6.0) [12] was applied. Microscopic study of micropreparations was performed with a microscope Micros 400 . Images were taken with a NiconColPix 4500 digital camera. Pictures were processed on a Pentium $2.4 \mathrm{GHz}$ computer using NiconView 5.

\section{Results and discussion}

At the time of sacrificing the animals, in all experimental groups that were observed survival rate was at $100 \%$.

During the histological study of kidney structure in all the rats in the control group was observed necrosis of the distal and proximal parts of the tubules of the nephrons with complete violation of the tissue pattern. The basement membrane of most necrotic tubules was destroyed. The accumulation of eosinophilic amorphous masses and cylinders can be seen in the lumen of the tubules of the cortico-medulla zone, the collecting ducts and the straight tubules of the renal medulla, as well as in the few preserved convoluted tubules

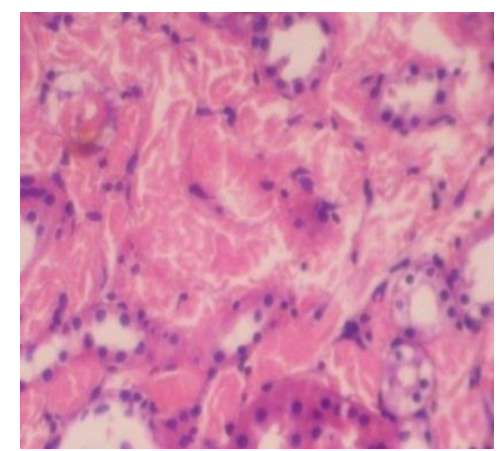

$a$

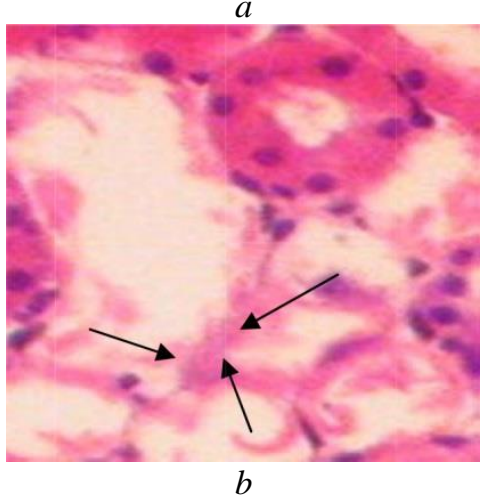

Fig. 2. Rat kidney with a model of glycerol acute renal failure for 3 days after the administration of glycerol: $a$ - necrosis of the distal and proximal parts of the tubules of the nephrons, vacuolal dystrophy of the nephrocytes of isolated preserved tubules; $b$-destruction of basement membranes (arrows) of necrotic tubules. Hematoxylin-eosin. $\times 200, \times 400$ 
On the background of administration of the compound "Indolinoren", was noted improvement of the tubal system of rat's nephrons. The necrotic changes were minimized in 4 out of 8 rats, there was no disruption and distortion of the nephrocytes of the distal and proximal parts of the tubules of the nephrons, visually reduced the number of tubules in the cortico-medullary zone and the cerebellum layer, the lumen of which was blocked by cylinders (Fig. 3).

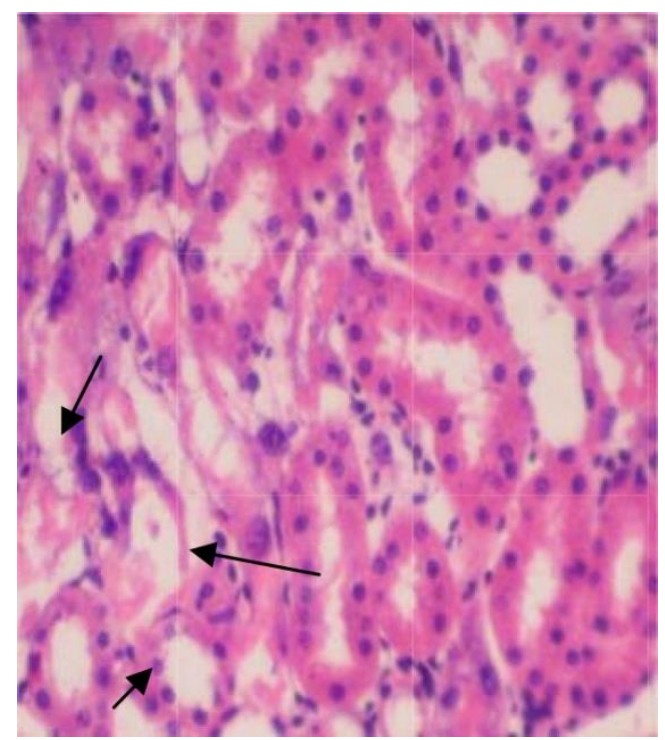

$a$

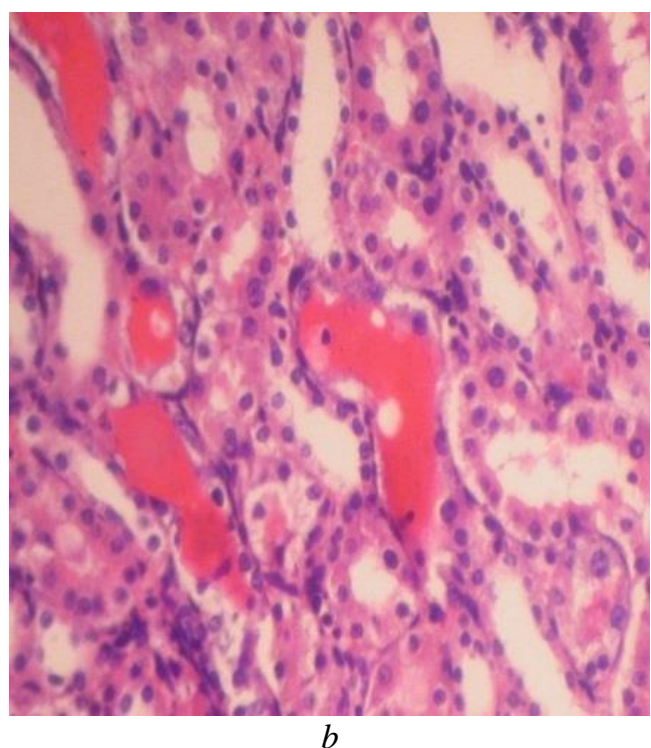

Fig. 3. Rat kidney with a model of glycerol acute renal failure with the introduction of "Indolinoren" on the

3rd day: $a$ - single-substituted convoluted tubules (arrows) on the background of intact; $b$ - reduction of cylinders in the channels of the cortico-medulla zone.

Hematoxylin-eosin. $\times 200$

The condition of the vast majority of renal glomeruli of all rats in this group practically did not change, except for individual glomeruli (Fig. 4).

After the administration of the drug comparison furosemide only one of the 8 rats had normal condition of the tubular renal system. The rest of the animals that was observed had dystrophic-necrotic chan- ges of the distal and proximal parts of the tubules of nephrons, ranging from weak ( 0.38 points $)$ to expressive (2.38 points) (Fig. 5).

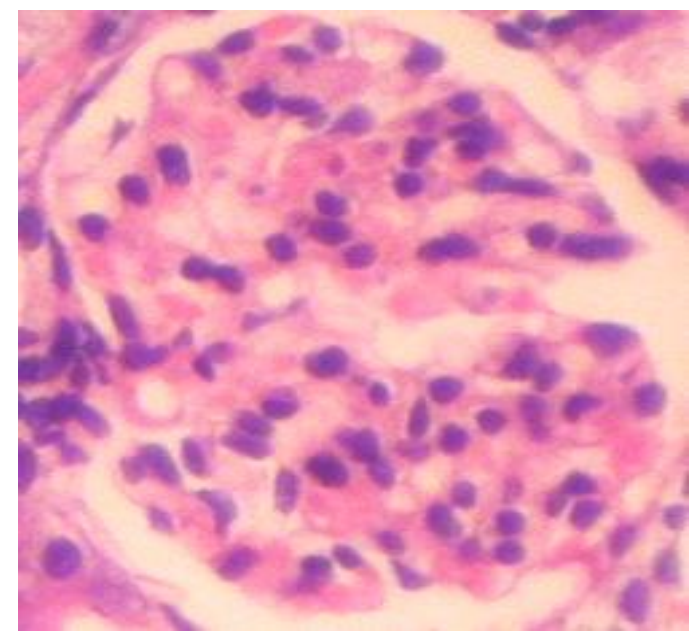

$a$

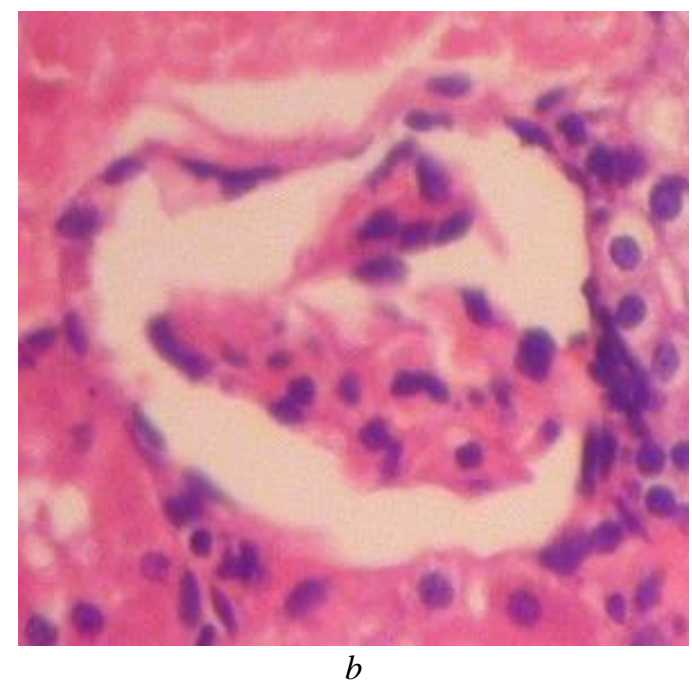

Fig. 4 Rat kidney with a model of glycerol acute renal failure on the background of the administration of

"Indolinoren" on the 3rd day: $a$ - kidney glomerulus corresponds to the norm; $b$-densely shaped kidney glomerulus, the pattern of capillary loops is not visualized. Hematoxylin-eosin. $\times 400$

The data of the semi-quantitative assessment of the condition of the tubular apparatus of the nephrons also indicate that on the model of glycerol ARF, the compound "Indolinoren" had a strong nephroprotective effect, significantly reducing the pathological changes in the system of tubular nephron compare to the control pathology (Table 1), reducing the severity of necrosis, vacuolic dystrophy and obstruction the lumen of the tubules by cylinders in 1.7 times. There is no reliable difference between the indicators for animals with ARF under the influence of the compound "Indolinoren" and furosemide comparison drug. Consequently, the new investigational compound "Indolinoren" on the severity of the normalizing effect on the histostructure of kidneys of rats with $\mathrm{ARF}$ is not inferior in compare to the loop diuretic furosemide 


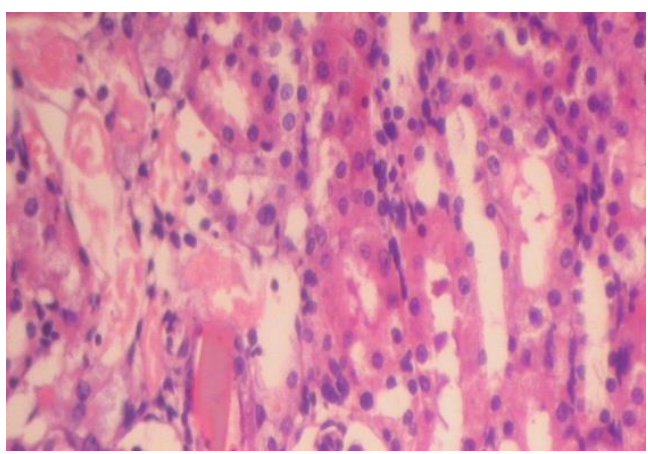

$a$

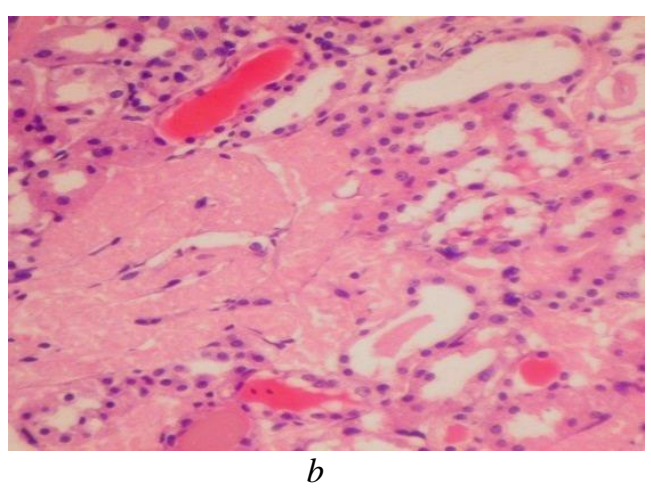

Fig. 5 Rat kidney with a model of glycerol acute renal failure on the background of the administration of furosemide on the 3rd day. Fluctuations in the severity of cortical tubular disorders: $a$ - weakly expressed ( 0.38 points); $b-$ strongly expressed (2.38 points). Hematoxylin-eosin. $\times 250, \times 200$

Table 1

Results of a semi-quantitative assessment of the effect of the investigated medications on damage of the tubular apparatus of rat's nephrons, points

\begin{tabular}{|l|c|c|c|c|}
\hline \multirow{2}{*}{\multicolumn{1}{|c|}{ Indicator }} & \multicolumn{4}{|c|}{ Groups of animals } \\
\cline { 2 - 5 } & $\begin{array}{c}\text { Intact control } \\
(\mathrm{n}=8)\end{array}$ & $\begin{array}{c}\text { Control pathology } \\
(\mathrm{n}=8)\end{array}$ & $\begin{array}{c}\text { Compound } \\
\text { "Indolinoren", } \\
29,5 \mathrm{mg} / \mathrm{kg}(\mathrm{n}=8)\end{array}$ & $\begin{array}{c}\text { Furosemide, } \\
5 \mathrm{mg} / \mathrm{kg}(\mathrm{n}=8)\end{array}$ \\
\hline Necrosis of nephrons & 0 & $3.44 \pm 0,09^{*}$ & $2.05 \pm 0.29 * / * *$ & $1.52 \pm 0.33^{*} / * *$ \\
\hline $\begin{array}{l}\text { Vacuolic dystrophy } \\
\text { nephrotelium }\end{array}$ & 0 & $2.19 \pm 0.13^{*}$ & $1.30 \pm 0.38^{*} / * *$ & $1.11 \pm 0.32^{* * * * *}$ \\
\hline $\begin{array}{l}\text { The presence of a } \\
\text { cylinder in the lumen } \\
\text { of the tubules }\end{array}$ & 0 & $3.18 \pm 0.17^{*}$ & $1.83 \pm 0.39 * / * *$ & $1.05 \pm 0.28^{*} / * *$ \\
\hline
\end{tabular}

Notes: deviations are probable in relation to intact control $(p<0.05) ; * *-$ deviations are probable relative to the control pathology ( $p<0.05) ; n$ - the number of animals in the group

The positive effect of furosemide and the compound "Indolinoren" on this experimental model is obviously due to their diuretic properties, which allows faster removal of the nephrotoxic substances circulating in the blood from the body [3, 6]. Thus, the toxic load and time of interaction with the toxicants decreases and as a consequence - the severity of the necrotic changes of the tubular system and, associated with them, the obstruction of the lumen of the various tubules decreases. It is also important that, among the damaged tubules, a substantial amount of basal membrane was preserved, which according to literature [13] contributes to the complete regeneration of these tubules. This is confirmed by regenerative manifestations in the nephrocytes, like mitosis and anisonucleosis.

\section{Conclusions}

1. According to the study of histostructure of kidneys on the glycerol acute renal failure model, the new compoundpropyl ester N-[(2-oxoindolinylidene-3)-2-oxacetyl] valine with the conditional name "Indolinoren" reduces the severity of necrosis of the nephrocytes of the tubules of the major parts of the nephrons and reduces the obstruction of the lumen of the tubules by homogeneous cylinders.

2. The new investigated compound "Indolinoren" on the severity of the protective effect on the histostructure of the renal kidneys of rats with glycerol acute renal failure syndrome is not inferior in compare to the diuretic furosemide.

3. The data obtained are the basis for further indepth study of the compound "Indolinoren" as a perspective diuretic.

\section{References}

1. Clinical Practice Guideline For Acute Kidney Injury [Text]. - Kidney International Supplements. - 2012. - Vol. 2, Issue 1. $-138 \mathrm{p}$.

2. Ivanov, D. D. Nefrologiya v praktitsi simeynogo likarya [Text] / D. D. Ivanov, O. M. Korzh. - Kyiv: Izdatelskiy dom "Zaslavskiy", 2014. - 464 p.

3. Ermolenko, V. M. Ostraya pochechnaya nedostatochnost [Text] / V. M. Ermolenko, A. Yu. Nikolaev. - Moscow: GeotarMedia, 2010. -240 p.

4. Nefrologiya: neotlozhnyie sostoyaniya [Text] / N. A. Muhin (Ed.). - Moscow: Eksmo, 2010. - 288 p.

5. Nefrologiya [Text] / E. M. Shilov (Ed.). - Moscow: GEOTAR-Media, 2010. - 697 p.

6. Markina, A. Yu. Eksperimentalnoe podtverzhdenie effektivnosti novogo proizvodnogo 2-oksoindolina - potentsialnogo diureticheskogo sredstva [Text] / A. Yu. Markina, T. I. Tyupka // Vestnik KAZNMU. - 2013. - № 5 (1). - P. $163-165$.

7. Markina, A. Yu. Vpliv Indolinorenu na perebig eksperimentalnoyi gostroyi nirkovoyi nedostatnosti [Text] / A. Yu. Markina, T. I. Tyupka // Ukrayinskiy biofarmatsevtichniy zhurnal. - 2013. - Vol. 2, Issue 25. - P. 50-53.

8. Shtrigol, S. Yu. Metodi eksperimentalnogo modelyuvannya urazhennya nirok dlya farmakologichnih doslidzhen [Text] / S. Yu. Shtrigol, V. M. Lisoviy, I. A. Zupanets, S. K. Shebeko et. al. - Kyiv, 2009. - 47 p. 
9. Kozhemyakin, Yu. M. Naukovo-praktichni rekomendatsiyi z utrimannya laboratornih tvarin ta roboti z nimi [Text] / Yu. M. Kozhemyakin, O. S. Hromov, N. E. Boldireva, N. V. Dobrelya, G. A. Sayfetdinova. - Kyiv: Interservis, 2017. - 156 p.

10. Protokol diagnostiki, profilaktiki i likuvannya gostrogo poshkodzhennya nirok (GPN) [Text]. - Ukrayinskiy zhurnal nefrologiyi ta dializu. - 2010. - Vol. 3. - P. 22-36.

11. Sokolovskiy, V. V. Gistohimicheskie issledovaniya v toksikologii [Text] / V. V. Sokolovskiy. - Leningrad: Meditsina, 1971. $-176 \mathrm{p}$.

12. Lapach, S. N. Statisticheskie metodyi v mediko-biologicheskih issledovaniyah s ispolzovaniem EXEL [Text] / S. N. Lapach, A. V. Chubenko, P. N. Babich. - Kyiv: MORION, 2001. - 408 p.

13. Strukov, A. I. Patologicheskaya anatomiya [Text] / A. I. Strukov, V. V. Serov. - Moscow: GEOTAR-Media, 2015. - 878 p.

Дата надходження рукопису 15.08.2017

Anna Markina, Senior Assistant, Department of Clinical Pharmacology, Institute of Pharmacy Professionals Qualification Improvement National University of Pharmacy, Zakhysnykiv Ukrainy sq., 17, Kharkiv, Ukraine, 61001

E-mail: Kolomanya7@gmail.com

Oksana Mishchenko, Doctor of Pharmaceutical Sciences, Professor, Head of Department, Department of Clinical Pharmacology, Institute of Pharmacy Professionals Qualification Improvement National University of Pharmacy, Zakhysnykiv Ukrainy sq., 17, Kharkiv, Ukraine, 61001

E-mail: clinpharmacol_ipksph@nuph.edu.ua

Julia Laryanovska, PhD, Senior Researcher, Central research laboratory, National University of Pharmacy, Pushkinska str., 53, Kharkiv, Ukraine, 61002

E-mail: cndl@nuph.edu.ua

UDC 615.322:633.13-035.261:616.379-008.64:57.084

DOI: 10.15587/2519-4852.2017.113503

\title{
NEW POSSIBILITIES OF USE OF OAT RAW MATERIALS FOR INVESTIGATION OF BIOLOGICALLY ACTIVE COMPONENTS IN THERAPY OF EXPERIMENTAL DIABETES
}

\author{
(C) L. Gayova, N. Yurzhenko, O. Mysnik
}

Метою роботи було запропонувати технологію аква динамічного екстрагування біологічно активних
речовин із соломи вівса. Встановлено, ще кількість екстракту та концентрація екстрагованих речовин
залежать від тривалості процесу екстракиії. Склад досліджуваного фітокомплексу доводився ядерно-
магнітним резонансом. Склад вищих жирних кислот фітокомплексу екстракту вівсяної соломи вивчали
иляхом газової хроматографії. Показана можливість використання фітокомплексу з екстракту соломи
вівса в дослідженні метаболізму ліпідів міокарду в експериментальних тварин з моделлю иукрового діа-
бету. Методи дослідження: оптимізували процес водного вилучення екстракту соломи вівса за допомогою динамічного характеру та підвищених температур, щзо може бути кращим очевидним недолікам, запропонованим раніше. Для того, щуоб оцінити відмінності в вмісті сумішей речовин, отриманих з первинного екстракту, було відзначено спостереження спектрів $H^{l}$-ЯМР в $D_{2} O$. Проведено газовохроматографічний аналіз спектру жирних кислот у досліджуваному фітокомплексі та ліпідів білих кров'яних клітин міокарда. Моделювання иукрового діабету проводилося иляхом внутрішньоклітинного введення стрептозотоцину в дозі 55 мг на кілограм маси тіла щурів протягом 6 тижнів.

Результати: був розроблений більш економічно доиільний підхід до одержання фітокомплексу шляхом екстрагування соломи вівса з повним збереженням біологічно активних речовин. Жирно-кислотний склад фітокомплексу екстракту вівсяної соломи вивчався газовою хроматографією. Розглянуто склад фітокомплексу екстракту соломи вівса за допомогою ядерно-магнітного резонансу

Висновки: Показано можливість використання фітокомплексу з екстракту вівсяної соломи в дослідженні метаболізму ліпідів міокарда в експериментальних тварин з моделлю иукрового діабету

Ключові слова: Avena Sativa, солома, екстракція, поліфеноли, антиоксиданти, жирні кислоти, експериментальний діабет

\section{Introduction}

The study of natural phytocomplexes permitted to distinguish a wide group of biologically active substances of polyphenolic nature, in particular, flavonoids. At the moment, a considerable number of scien- tifically-practical researches aimed at studying polyphenol component of numerous products of economic activity, such as wine [1], some agricultural products $[2,3]$, and herbs, among which lists the oat, Avena Sativa, in its various natural and synthetic forms, are 